\title{
Bioenergy Production from Paper Mill Sludge through Anaerobic Digestion
}

\author{
G. Saravanapriya ${ }^{*}$ and R. Shreelavaniya \\ ICAR Bioconversion Technology Centre, Sri Parasakthi College for Women, \\ Courtallam, Tenkasi, Tamil Nadu, India \\ *Corresponding author
}

\section{A B S T R A C T}

\section{Keywords}

Paper mill sludge, Biogas, Anaerobic, Digestion, Energy

\section{Article Info}

\section{Accepted:}

07 January 2021

Available Online:

10 February 2021
Paper mill sludge is the organic waste obtained from the waste water treatment of paper and pulp industries. It mainly contains cellulosic fibres, which is dumped in road sides without any use. The aim of this present study is to analyze the potential of energy generation from paper mill sludge through anaerobic digestion process and to find the optimum percentage of paper mill sludge for replacing cow dung during anaerobic digestion process. It not only generates energy in the form of biogas but also reduces environmental pollution through dumping of waste sludge. The paper mill sludge was collected from nearby paper mill and laboratory experiments using 51 Hofkins flask and field experiment in $2 \mathrm{~m}^{3}$ KVIC biogas plant was conducted to identify the biogas production from paper mill sludge. The gas production for various percentage of paper mill sludge during laboratory experiments ranged from 88.78 litre/kg of dry matter to 179.27 litre/kg of dry matter whereas in control the range is 147.01 litre/kg of dry matter to 171.39 litre/kg of dry matter. The maximum gas production was recorded in $50 \%$ and $55 \%$ paper mill sludge substitution in laboratory study using bottling experiments. In case of field experiments, the maximum gas production of 206.08 litre/kg dry matter was observed in $60 \%$ paper mill sludge substitution compared to 201.34 litre/kg dry matter in control.

\section{Introduction}

Paper industry is the most polluted industry (Thompson et al., 2001) and the processes are energy and water intensive processes (Pokhrel and Viraraghavan, 2004). Paper industries discharge large quantities of wastewater and sludge which mainly consists of cellulose and inorganic material. The quantity of sludge produced ranging from 0.3 to $1 \mathrm{~m}^{3}$ per ton of paper production (Priadi et al., 2014). The sludge produced is usually dewatered upto a solids concentration of 20-45 \% and subsequently dumped at landfill sites, which results in high disposal costs and creates environmental pollution. On the other hand, the organic part of the waste material may be considered as a potential source for the production of renewable energy in the form of methane through anaerobic digestion. Recent advances in the microbiology and technology of anaerobic digestion have led to a broad application of this process to the treatment of industrial wastewaters (Sahm, 1984; Van den Berg, 1984) and sludge. 
Disposal of solid organic waste when it is in wet condition is very much expensive, whereas thermal destruction is also expensive and energy-demanding. Efforts have therefore been made to minimize the production of sludge by using advanced biological treatment processes (Mahmood and Elliott, 2006). The anaerobic digestion of paper mill sludge to biogas not only reduces the volume of sludge also generates renewable energy that can displace natural gas in industrial processes (Mahmood and Elliott, 2006; Deubelin and Steinhauser, 2008).

Anaerobic digestion is the most common method used to stabilize sludge from paper industry. It uses various anaerobic bacteria to degrade the sludge and produces biogas including methane, which is an alternative source of energy and that can be substituted for energy from fossil fuels in paper industries. Anaerobic digestion has been successfully used for various kinds of sludge treatments. However, very few studies have reported anaerobic digestion for paper mill sludge (Priadi et al., 2014).

The paper-pulp, paper mill and dairy industries are an important part of the economy in many countries. These industries are the greatest consumer of water and also the greatest loading generators of industrial solid wastes such as, fly ash, bark, silt, general mill sweepings, inorganic precipitates and solid sludge from complex wastewater treatment facilities. The sludge are frequently incinerated or disposed of in land fill sites. Both methods lead to the loss of profitable resource and have obvious environmental and economic disadvantages (Elvira et al., 1997).

Sludge is the solid residue formed during wastewater treatment (mixed with water). Two types of sludge materials are disposed off daily from the paper mill. One type of sludge contains $50 \%$ organic material and
$50 \%$ inorganic material. Other type of sludge contains $20 \%$ organic material and $80 \%$ inorganic material. Hence, the investigation was carried out using the first type (50:50) sludge.

\section{Materials and Methods}

The laboratory experiments on batch fermentation were carried out in 5 litreHofkin flasks with various proportions of paper mill sludge from $10 \%$ to $85 \%$ supplemented with cow dung. The experimental setup was maintained for a period of 60 days. Daily gas production was also recorded using water displacement method.

After completion of laboratory experiments, the field experiment was carried out in 2 cu.m. KVIC biogas plants. The field experiment was carried out with 2 cu.m biogas plants. One plant was fed with cow dung alone maintaining as control and the other plant was fed with paper mill sludge with gradual replacement of cow dung. The biogas plant was fed with various percentages of paper mill sludge with gradual replacement of cow dung in incremental dose from $10 \%$ substitution and the work was completed up to $90 \%$ paper mill sludge substitution. Paper mill sludge has been substituted in the place of cow dung with $10 \%$ addition in every four weeks period. As the paper mill sludge contain $36.80 \%$ total solids, with various percentage of paper mill sludge substitution, sufficient quantity of water was added to maintain the TSC at $10 \%$ level. Before feeding, the paper mill sludge was soaked in water overnight to make uniform slurry. When plant was fed with paper mill sludge, the sampling was taken every week and the percentage was maintained for 30 days each. Gas production during field experiments was also recorded using gas flow meter with 10 90\% replacement in the treatment plant. 
The biochemical constituents of the raw paper mill sludge, initial and final slurry samples from laboratory experiments and field experiments were analyzed. The dry matter content of the samples was estimated by complete drying and successive weighing till constant weight is achieved (APHA, 1975). Nitrogen was estimated using Micro kjeldhal methods of Jackson (1958), Phosphorus was estimated by the method of Fiske and Subbarow (1925). Potassium and Sodium were measured by Flame photometric method given in APHA (1975). Organic carbon was estimated by the method of Black et al (1951). The Cellulose and Hemi cellulose were determined by the method given by Updegraff (1969) and Horwitz (1960) respectively.

\section{Results and Discussion}

The biochemical constituents of raw paper mill sludge are given in Table 1 . The total solid and volatile solid content was found to be $39.32 \%$ and $49.98 \%$ respectively. According to Gijzen et al., 1990, the total solid of paper mill sludge was $39.8 \%$ and volatile solid was $42.6 \%$. These values are comparable with the results of biochemical composition of paper mill sludge in the present study. As reported by Lin et al., 2013, the organic carbon and total nitrogen content in paper mill sludge was $34.75 \%$ and $1.12 \%$, which supports the results of present analysis. As reported in literature, the range of $\mathrm{C}: \mathrm{N}$ ratio of 20:1 to 30:1 materials can be used as a substrate for biogas production. The $\mathrm{C}: \mathrm{N}$ ratio of paper mill sludge was found to be 21.43, which makes it suitable as a substitute for cow dung in biogas production.

The operational $\mathrm{pH}$ of the anaerobic digestion affects the digestive process. The fermentation microorganisms can function in the range of $4-8.5$ (Hwang et al., 2004). The ideal $\mathrm{pH}$ range for anaerobic digestion has been reported as 6.8 - 7.4 (Igoni, 2003). The $\mathrm{pH}$ of the slurry samples before and after digestion of each batches were recorded. The $\mathrm{pH}$ of the initial slurry samples was in the range of $6.4-7.8$ and that of final slurry samples were 6.7 - 8.8. In the initial phase of anaerobic digestion process, the production of Volatile fatty acids (VFA) decreases the $\mathrm{pH}$ of the slurry. But the reaction of $\mathrm{CO}_{2}$ which is soluble in water with hydroxide ion forming bicarbonate ions, so forming $\mathrm{HCO}_{3}$, tends to restore the neutrality of the process $\mathrm{pH}$. When rate of acid formation exceeds the rate of breakdown to methane, the process imbalance which results in $\mathrm{pH}$ decrease.

Table.1 Biochemical Composition of sludge (50:50)

\begin{tabular}{|c|l|c|}
\hline S.No. & \multicolumn{1}{|c|}{ Constituents } & Value, $\%$ \\
\hline $\mathbf{1 .}$ & Moisture & 60.68 \\
\hline $\mathbf{2 .}$ & pH & 8.8 \\
\hline $\mathbf{3 .}$ & Total Solids & 39.32 \\
\hline $\mathbf{4 .}$ & Volatile Solids & 49.98 \\
\hline $\mathbf{5 .}$ & Organic Carbon & 27.00 \\
\hline $\mathbf{6 .}$ & Nitrogen & 1.26 \\
\hline $\mathbf{7 .}$ & Phosphorous & 0.528 \\
\hline $\mathbf{8 .}$ & Potassium & 0.19 \\
\hline $\mathbf{9 .}$ & Sodium & 0.71 \\
\hline $\mathbf{1 0 .}$ & Cellulose & 12.96 \\
\hline $\mathbf{1 1 .}$ & Hemi cellulose & 2.78 \\
\hline $\mathbf{1 2}$ & Lignin & 5.87 \\
\hline
\end{tabular}


Table.2 Gas production for various percentage of paper mill sludge substitution

\begin{tabular}{|c|c|c|c|c|c|}
\hline \multirow{2}{*}{$\begin{array}{l}\text { S. } \\
\text { No. }\end{array}$} & \multirow[t]{2}{*}{ Treatments } & \multirow{2}{*}{$\begin{array}{c}\text { Total Solids, } \\
\%\end{array}$} & \multirow{2}{*}{$\begin{array}{c}\text { Gas Production, } \\
\text { litre/kg of dry } \\
\text { matter }\end{array}$} & \multicolumn{2}{|c|}{ Temperature, ${ }^{\circ} \mathrm{C}$} \\
\hline & & & & Min. & Max. \\
\hline 1. & Control 1 & 10.31 & 155.25 & 26 & 30 \\
\hline 2. & $10 \%$ PMS + $90 \%$ cow dung & 10.34 & 104.02 & 26 & 30 \\
\hline 3. & $15 \%$ PMS $+85 \%$ cow dung & 10.29 & 121.57 & 26 & 30 \\
\hline 4. & $20 \%$ PMS $+80 \%$ cow dung & 10.21 & 150.02 & 26 & 30 \\
\hline 5. & $25 \%$ PMS $+75 \%$ cow dung & 10.02 & 153.67 & 26 & 30 \\
\hline 6. & Control 2 & 10.39 & 171.39 & 27 & 33 \\
\hline 7. & $30 \%$ PMS $+70 \%$ cow dung & 9.96 & 148.45 & 27 & 33 \\
\hline 8. & $35 \%$ PMS + $65 \%$ cow dung & 10.03 & 161.09 & 27 & 33 \\
\hline 9. & $40 \%$ PMS $+60 \%$ cow dung & 9.88 & 161.87 & 27 & 33 \\
\hline 10. & $45 \%$ PMS $+55 \%$ cow dung & 8.63 & 167.74 & 27 & 33 \\
\hline 11. & Control 3 & 10.34 & 147.01 & 27 & 33 \\
\hline 12. & $50 \%$ PMS + 50\% cow dung & 10.63 & 179.27 & 27 & 33 \\
\hline 13. & $55 \%$ PMS + $45 \%$ cow dung & 10.09 & 179.08 & 27 & 33 \\
\hline 14. & $60 \%$ PMS + $40 \%$ cow dung & 10.27 & 164.04 & 27 & 33 \\
\hline 15. & $65 \%$ PMS $+35 \%$ cow dung & 10.67 & 151.17 & 27 & 33 \\
\hline 16. & Control 4 & 11.52 & 154.75 & 26 & 31 \\
\hline 17. & $70 \%$ PMS $+30 \%$ cow dung & 11.26 & 129.88 & 26 & 31 \\
\hline 18. & $75 \%$ PMS $+25 \%$ cow dung & 11.72 & 120.75 & 26 & 31 \\
\hline 19. & $80 \%$ PMS $+20 \%$ cow dung & 11.97 & 106.94 & 26 & 31 \\
\hline 20 & $85 \%$ PMS $+15 \%$ cow dung & 11.60 & 88.78 & 26 & 31 \\
\hline
\end{tabular}

*PMS - Paper Mill Sludge

Table.3 Gas production for various percentage of paper mill sludge substitution in field experiments

\begin{tabular}{|c|c|c|c|c|c|}
\hline \multirow[t]{2}{*}{ S. No. } & \multirow[t]{2}{*}{ Treatments } & \multirow{2}{*}{$\begin{array}{c}\text { Total Solids, } \\
\%\end{array}$} & \multirow{2}{*}{$\begin{array}{l}\text { Gas Production, } \\
\text { litre/kg of dry } \\
\text { matter }\end{array}$} & \multicolumn{2}{|c|}{ Temperature, ${ }^{\circ} \mathrm{C}$} \\
\hline & & & & Min. & Max. \\
\hline \multirow[t]{2}{*}{1.} & Control & 9.70 & $190.18 \pm 7.10$ & 26 & 30 \\
\hline & $10 \%$ PMS + $90 \%$ cow dung & 9.75 & $198.05 \pm 8.50$ & 26 & 30 \\
\hline \multirow[t]{2}{*}{2.} & Control & 10.25 & $189.89 \pm 4.39$ & 26 & 30 \\
\hline & $20 \%$ PMS $+80 \%$ cow dung & 9.98 & $190.12 \pm 5.07$ & 26 & 30 \\
\hline \multirow[t]{2}{*}{3.} & Control & 9.73 & $183.60 \pm 7.71$ & 27 & 31 \\
\hline & $30 \%$ PMS $+70 \%$ cow dung & 10.03 & $172.18 \pm 2.09$ & 27 & 31 \\
\hline \multirow[t]{2}{*}{4.} & Control & 9.80 & $186.41 \pm 2.87$ & 28 & 31 \\
\hline & $40 \%$ PMS $+60 \%$ cow dung & 9.99 & $185.89 \pm 7.07$ & 28 & 31 \\
\hline \multirow[t]{2}{*}{5.} & Control & 9.82 & $190.55 \pm 1.41$ & 30 & 31 \\
\hline & $50 \%$ PMS $+50 \%$ cow dung & 9.92 & $188.48 \pm 1.20$ & 30 & 31 \\
\hline \multirow[t]{2}{*}{6.} & Control & 10.02 & $176.30 \pm 7.13$ & 29 & 31 \\
\hline & $60 \%$ PMS $+40 \%$ cow dung & 9.75 & $206.08 \pm 1.34$ & 29 & 31 \\
\hline \multirow[t]{2}{*}{7.} & Control & 10.01 & $201.34 \pm 4.33$ & 28 & 30 \\
\hline & $70 \%$ PMS $+30 \%$ cow dung & 10.19 & $181.79 \pm 0.91$ & 28 & 30 \\
\hline \multirow[t]{2}{*}{8.} & Control & 9.89 & $198.84 \pm 2.38$ & 28 & 31 \\
\hline & $80 \%$ PMS $+20 \%$ cow dung & 9.94 & $158.26 \pm 1.21$ & 28 & 31 \\
\hline \multirow[t]{2}{*}{9.} & Control & 10.21 & $191.24 \pm 4.36$ & 28 & 31 \\
\hline & $90 \%$ PMS $+10 \%$ cow dung & 9.97 & $131.13 \pm 3.12$ & 28 & 31 \\
\hline
\end{tabular}

*PMS - Paper Mill Sludge 
Fig.1 Gas production per kg of dry matter for various proportions of paper mill sludge in laboratory experiments

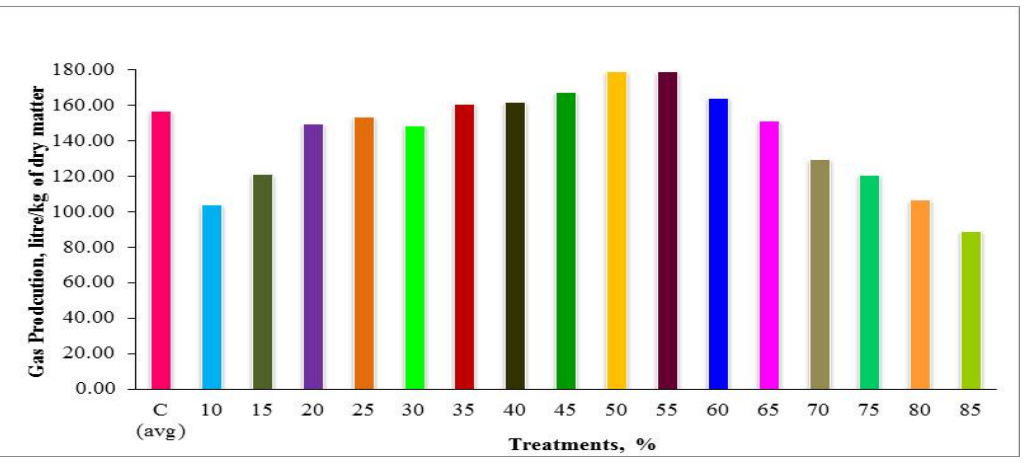

Fig.2 Gas production per $\mathrm{kg}$ of dry matter for various proportions of paper mill sludge in field experiments

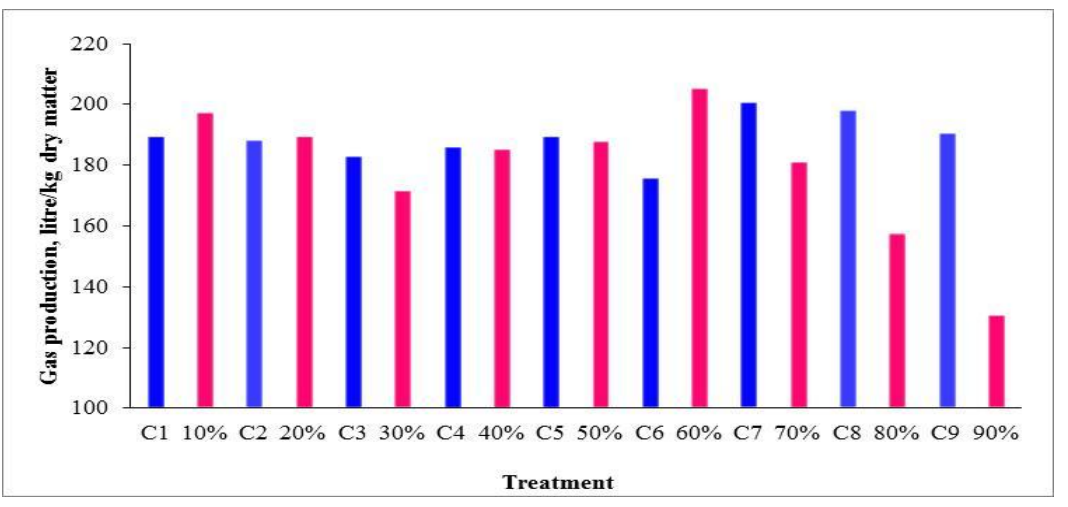

There is a reasonable reduction in total solids and volatile solid content of final slurry samples in all treatments of various batches. The total solid content of outlet slurry was higher in all treatments than control of respective batches. This might be due to additional solids present in the paper mill sludge. Similar trend was also observed in volatile solid content also. The organic carbon of inlet slurry is much higher than outlet slurry in all treatments, which showed that the carbon content was converted as $\mathrm{CO}_{2}$ during anaerobic digestion process. The nitrogen content of inlet and outlet slurry of control was higher than the other treatments. In case of phosphorus, potassium and sodium, the outlet slurry has higher value than inlet samples in all treatments.
The digestion period for all the treatments was given as 60 days. The gas production per $\mathrm{kg}$ of total solid content was estimated for various treatments of paper mill sludge substitution in laboratory experiments and is given in Table 2. The gas production for various percentage of paper mill sludge ranged from 88.78 litre $/ \mathrm{kg}$ of dry matter to 179.27 litre $/ \mathrm{kg}$ of dry matter whereas in control the range is 147.01 litre $/ \mathrm{kg}$ of dry matter to 171.39 litre/kg of dry matter. From the Fig. 1, the maximum gas production was recorded in $50 \%$ and $55 \%$ paper mill sludge substitution.

The digestion period for all the treatments in field experiment was given as 30 days. Gas production was also recorded using gas flow meter. The gas production per $\mathrm{kg}$ of total solid 
content was estimated for various treatments of paper mill sludge substitution in field experiments and is given in Table 3.

The total gas production throughout the period of anaerobic digestion for paper mill sludge substitution from $10 \%-90 \%$ and control are given in Fig. 2. The gas production for treatment plant is in the range of 131.13 - 206.08 litre/kg of dry matter whereas in control plant it is 176.30 - 201.34 litre/kg of dry matter. From the Fig. 2, the maximum gas production of 206.08 litre $/ \mathrm{kg}$ dry matter was recorded in $60 \%$ paper mill sludge substitution. The gas production is higher in field of $60 \%$ paper mill sludge with $40 \%$ cow dung. The field experiment for $70-90 \%$ paper mill sludge substitution the gas production is gradually reduced.

In conclusion, the laboratory experiments were completed and based on the results, the paper mill sludge can be effectively utilized for biogas production upto $65 \%$ replacement. The field experiment was carried out with 2 cu.m biogas plants and gas production was also recorded using gas flow meter with 10 $90 \%$ replacement of cow dung with paper mill sludge in the treatment plant. The maximum gas production of 206.08 litre/kg dry matter was observed in $60 \%$ paper mill sludge substitution with maximum gas production of 201.34 litre/kg dry matter in control. Based on field experiments upto $90 \%$ paper mill sludge substitution, the maximum gas production was recorded in $60 \%$ paper mill sludge substitution.

\section{References}

American Public Health Association (APHA).1975. Standard methods for the examination of water and waste water. 15th Ed. Washington. D.C.

Black C.A., Evans, D.D., White,
J.L.,Engminger, L.E., and Clark, F.E. 1965 Methods of soil analysis Part - 2. Chemical and Microbiogical properties, American Society of Agronomy, Academic Pres, New York, 1374 . 1376.

Deublein, D., and Steinhauser, A. 2008. Biogas from waste and renewable resources: An introduction. Wiley-VCH Verlag $\mathrm{GmbH}$ and Co., Germany.

Elvira, C., and Albareda, P. 1996. Bioconversion of solid paper-pulp mill sludge by earthworms, 57: 173-177.

Fiske, C.M. and Subbarow, V. 1925. The colorimetric determination of phosphorus, J. biol.chem.66: 375 - 40.

Gijzen, H. J., Derikx, P. J. L., and Vogels, G. D. 1990. Application of Rumen Microorganisms for a High Rate Anaerobic Digestion of Paper mill Sludge, Biological wastes.32, 169-179.

Horwitz W. 1960. Official methods of analysis of AOAC, Washington. D.C., U.S.A.

Hwang, M. H., Jang, N.J., Hyum, S. H., and Kim, I.S. 2004. Anaerobic bio-hydrogen production from ethanol fermentation: the role of $\mathrm{pH}$, J.Biotechnol. 111: 297 309.

Igoni, A. H., Ayotamuno, M. J., Eze, C. L., and Ogaji, S. O. T. 2008.Applied Designs of anaerobic digesters for producing biogas from municipal solidwaste, Applied Energy 85: 430-438. doi:10.1016/j.apenergy.2007.07.013

Jackson. M.L. 1958.Soil Chemical analysis, Prentice Hall of India Pvt. Ltd., New Delhi 187 - 190.

Lin, Y., Wu, S., and Wang, D. 2013.Hydrogen-methane production from pulp \& paper sludge and food waste by mesophilic - thermophilic anaerobic co-digestion. International Journal of Hydrogen Energy, 38(35): 15055-15062.

doi:10.1016/j.ijhydene.2012.01.051 
Mahmood, T., and Elliott, A. 2006.A review of secondary sludge reduction technologies for the pulp and paper industry. Water Res. 40: 2093 - 2112.

Pokhrel, D., and Viraraghavan, T. 2004. Treatment of pulp and paper mill wastewater: a review. Science of The Total Environment, 333 (1-3): 37-58.

Priadi, C., Wulandari, D., Rahmatika, I., and Moersidik, S. S. 2014. Biogas Production in the Anaerobic Digestion of Paper Sludge. Procedia - Social and Behavioral Sciences, 9 (Icbee 2013), 65-69.

doi:10.1016/j.apcbee.2014.01.012
Sahm, H. 1984. Anaerobic waste water treatment.In Advances in Biochemical Engineering Biotechnology, 29, ed. A. Fiechter. Springer, Berlin, 83-115.

Thompson, G., Swain, J., Kay, M., and Forster, C. 2001. The treatment of pulp and paper mill effluent: a review. Bioresource Technology 77: 275-286.

Updegraff, D.M., 1969.semimicro determination of cellulose in biological materials. Anal. Biochem.32:420-424.

Van den Berg, L. 1984. Developments in methanogenesis from industrial waste water.Can. J. MicrobioL. 30: 975-90.

\section{How to cite this article:}

Saravanapriya, G. and Shreelavaniya, R. 2021. Bioenergy Production from Paper Mill Sludge through Anaerobic Digestion. Int.J.Curr.Microbiol.App.Sci. 10(02): 538-544. doi: https://doi.org/10.20546/ijcmas.2021.1002.064 